\title{
CONSUMER BEHAVIOUR IN ONLINE SHOPPING ORGANIC FOOD DURING THE COVID-19 PANDEMIC IN SERBIA
}

\author{
Maja R. Ćirić*, Dragan S. Ilić, Svetlana D. Ignjatijević, Sandra D. Brkanlić \\ Faculty of Economics and Engineering Management, 21000 Novi Sad, Cvećarska 2, Serbia
}

\begin{abstract}
The purpose of this paper was to determine whether the Covid-19 Pandemic influenced the change in the extent of online shopping of organic food in Serbia and whether it has led to a change in organic food consumer behaviour. The survey was carried out in Serbia by using a questionnaire developed specifically for this purpose. The total sample size included 1022 respondents of which 90 respondents were online buying organic food during Covid-19 Pandemic. Descriptive statistics and Chi-square test were used to analyse data obtained from the survey. The results indicate that the Covid-19 Pandemic influenced the increase in the percentage of consumers who purchase organic food online. Also, the changes in the type and volume of organic food consumption were identified. Besides, the consumption of organic food varied in relation to the sociodemographic characteristics of consumers who purchased online.
\end{abstract}

Key words: consumer behaviour, organic food, online shopping, pandemic, Covid-19

\section{INTRODUCTION}

Little research has been conducted on how consumers behave in online shopping of organic food. The reason for less interest in studying this issue can be found in the fact that the percentage of consumers who buy organic food online in the previous years was low. In a survey conducted in Poland (Bryła, 2018) on a sample of 1000 respondents, only $6.3 \%$ consumers buy organic food online. Moreover, Bryła (2018) showed that those consumers, who buy organic food online, in addition to the Internet, use other sales channels to buy organic food which at first glance may indicate the relatively small importance of online shopping for organic food compared to traditional channels of selling organic food (Cane, 2018). The results of studies conducted in Malaysia showed that only
$2.3 \%$ of respondents buy organic food using online shopping websites while the remaining 97.7\% purchase organic food products from supermarkets, convenience stores, or other sources (Hasanov \& Khalid, 2015). In the research that was conducted in Serbia in previous years (Stojić \& Dimitrijević, 2020; Palić et al., 2019; Končar, 2019; Kranjac, Vapa-Tankosić \& Knežević, 2017; Vlahović \& Šojić, 2016), during the analysis of the sales channels through which consumers most often buy organic food, online shopping was not even examined. This indicates that this type of organic food purchase remains underdeveloped in Serbia. Confirmation of our position is the result of research by Dašić et al. (2019) in which the authors came to the conclusion that only $6.6 \%$ of consumers in 
Serbia buy organic food online. However, in a study conducted in China (Wanmei, 2018) it was pointed out that with the increase in the use of the Internet, there has been a development of online shopping of organic products in recent years and that the number of consumers who buy organic food online has been increasing. In a study conducted in Indonesia (Hasan \& Suciarto, 2020) it was pointed out that consumers face a limited supply of organic food in offline stores that sell organic food, while online shops sell all kinds of organic foods that are not sold in supermarkets. Social media Instagram was also cited as very useful for consumers in Indonesia who want to buy organic food. A study conducted in India found that $23.8 \%$ of respondents used to purchase organic products in online shopping. Examinees answered that online shopping helps the customers to purchase organic products easily without moving from various places. However, examinees believe that the online service needs to be improved, in order to enable them to shop as safely as possible (Mohanraj, Sureshkumar \& Jaganathan, 2019). Such trends in consumer behaviour in China, Indonesia and India indicate that in the future, online shopping of organic food could gain in importance in other countries around the world as well and that consequently it is necessary to focus attention and explore consumer behaviour in online shopping of organic food, so that this type of shopping can be improved and harmonized with the wishes and expectations of consumers.

According to Končar et al. (2019), insufficient attention has been paid to organic production, placement and consumption in the Serbian market. The data show that in Serbia the share of organic land in the total agricultural land is only $0.44 \%$ or 15,000 ha with a total of 2,000 agricultural producers and processors. Compared to EU countries where the placement of organic food products grows at an annual rate of 10$15 \%$ this growth rate in Serbia is estimated at only 2 to $3 \%$. This figure shows there is a lot of opportunity for the improvement of organic food placement and consumption in Serbian market.

Besides product and consumer characteristics, consumer behavior in shopping is also influenced by situational factors (Wanmei, 2018; Hasan \& Suciarto, 2020; Aschemann-Witzel \& Zielke, 2017). Therefore we considered that is important to determine how the occurrence of the Covid-19 Pandemic affected consumer behaviour and their habits in online shopping of organic food. The Covid-19 pandemic is a typical example of how consumer behaviour depends not only on product and consumer characteristics but also on the situation. However, as no situational factor always affects all consumers in the same manner, as well as the purchase of all types of products, the main goal of our research was to determine how the Covid19 Pandemic affected the online purchase of organic food in Serbia. Namely, we tried to determine what percentage of consumers bought organic food online before the Covid-19 Pandemic and whether there were changes during the Covid-19 Pandemic in terms of increasing or decreasing consumers who buy organic food online; Did consumers who bought organic food online during the Covid-19 Pandemic experience change in the type of organic food and the amount of organic food consumed during the Covid-19 Pandemic compared to the previous period?; Are there differences in the amount of organic food consumption depending on the demographic characteristics of consumers who bought organic food online during the Covid-19 Pandemic?

\section{MATERIALS AND METHODS}

The research was conducted at the beginning of April 2020, when a state of emergency was introduced in Serbia due to the Covid-19 Pandemic. At that time, measures were in force: limited movement of people, suspension of public transport, the closing of markets, and limitation of working hours of specialized stores and supermarkets. The survey instrument was questionnairy and questions were created in the Google questionnaire. The total number of distributed questionnaires was 1500 , to which 1275 (85\%) respondents answered. Respondents, residents of cities in Serbia (1022) were singled out from that number, considering that the residents of cities in Serbia were most affected by the measures due to the Covid-19 Pandemic. Besides, we had in mind that the great awareness about the importance of organic food prevails among consumers living in urban areas. In addition, the greatest demand for organic products is in bigger cities (Dašić et al., 2019). The number of respondents was narrowed down to those who bought organic food online during the Covid-19 Pandemic. Their number was 90 ( $8.8 \%$ of city respondents). Thus, we obtained a sample of those res- 
pondents who bought organic food online during the Covid-19 Pandemic, for detailed analysis. That sample consisted of 21 male and 69 female respondents. The age structure of the respondents was the following: 21 respondents were younger than $24 ; 30$ respondents were between 25 and 39; 36 respondents were between 40 and 60; and 3 respondents were above 61 . The educational structure was the following: 39 respondents had high school; 18 respondents had bachelor's degree; and 33 respondents had master and $\mathrm{PhD}$. The income of household structure was: less than 500 euros per household had 15 respondents; 30 respondents had between 501 and 1000 euros; 24 respondents had between 1001 and 2000 euros and 21 respondents had above 2001 euros per household. The household member structure was: 21 respondents lived in one-member and two-member households; 30 respondents lived in three-member and four-member households; while 39 respondents lived in households with five and over five members.

The respondents were selected using the "snowball" method, by sending the link to the questionnaire to the email addresses of a large number of respondents with a request to forward the link. This method enabled as many respondents as possible to be included in the research especially because the online purchases of organic produce are on a low awareness within consumers (Venter et al., 2011) and there is not so much data in the scientific literature in that field. Data processing was performed using the SPSS program for statistical data processing. Descriptive statistics and ChiSquare were used to analyse the phenomena in detail.

The main hypothesis: Consumers changed their behaviour in online shopping organic food during Covid-19 Pandemic.

Additional hypotheses:

1. There is an increase in online shopping organic food during Covid-19 Pandemic.

2. There is a change in the consumption of the type of organic food during Covid-19 Pandemic.

3. There is an increase in percentage of organic food in total food consumption during the Covid-19 Pandemic.

4. There is a difference in the share of organic food in total food consumption during the Covid-19 Pandemic depending on consumer's demographic factors.

\section{RESULTS AND DISCUSSION}

Table 1 shows the number and percentage of respondents who bought organic food online before and during the Covid-19 Pandemic. According to the results of the Chi-Square test, there was a statistically significant difference in the consumption of organic food before and during Covid-19 pandemic. The online purchase of organic food before the Covid-19 Pandemic was slightly lower compared to the research conducted in Serbia in January 2019 (Dašić et al., 2019) according to which the percentage of consumers who buy organic food online was $6.6 \%$. The slightly higher percentage in the mentioned research was most likely because it was conducted in Belgrade, the capital of Serbia, where consumers with the greatest tendency to shop online are concentrated, whereas in our sample consumers were from several cities in Serbia. When we look at the percentage of consumers who answered that they buy organic food online during the Covid-19 Pandemic, we see that there has been an increase in consumers who buy organic food online $(8.81 \%)$. Although the percentage of online buyers increased by only $3.53 \%$ in the total sample, this increase cannot be ignored. It is necessary to keep in mind that the initial percentage of consumers who buy organic food online was 5.28\% and that during the Pandemic there was an increase by $66.67 \%$. The result indicated that the Covid-19 Pandemic affected the shopping habits of organic food consumers in such a way that $1 \%$ of consumers who previously did not use online shopping as a way of buying organic food, changed their habit and begun using online shopping. Respondents who bought organic food online during the Covid-19 Pandemic answered what kind of organic food they consumed before and during the Covid-19 Pandemic (they had the opportunity to round out multiple responses) (Table 2). It can be observed that the consumption of organic food before the Covid-19 Pandemic was dominated by the consumption of vegetables and fruits. Milk, dairy products, eggs, cereals, flour, and pasta were approximately equally represented. Meat and cured meat products were the least represented, not counting the rest category. 
Table 1. Percentage of respondents who bought organic food online before and during the Covid-19 Pandemic

\begin{tabular}{lcccc}
\hline & \multicolumn{2}{c}{ Before the Covid-19 pandemic } & \multicolumn{2}{c}{ During the Covid-19 pandemic } \\
\cline { 2 - 4 } & Frequency & Percent & Frequency & Percent \\
\hline Yes & 54 & 5.28 & 90 & 8.81 \\
No & 968 & 94.72 & 932 & 91.19 \\
\hline Total & 1022.0 & 100.0 & 1022.0 & 100.0 \\
\hline $\begin{array}{l}\text { Pearson Chi-Square value } 9.682105 \\
\text { df } 1\end{array}$ & & & \\
Asymp. Sig. (2-sided) 0.01 & & & \\
\hline
\end{tabular}

Table 2. Consumption of organic food by types before and during the Covid-19 Pandemic

\begin{tabular}{lcccc}
\hline \multirow{2}{*}{ Organic food types } & \multicolumn{2}{c}{ Before the Covid-19 Pandemic } & \multicolumn{2}{c}{ During the Covid-19 Pandemic } \\
\cline { 2 - 5 } & Frequency & Percent & Frequency & Percent \\
\hline Vegetables & 69 & 76.7 & 54 & 60.0 \\
Fruits & 57 & 63.3 & 63 & 70.0 \\
Milk and dairy products & 38 & 42.2 & 36 & 40.0 \\
Eggs & 36 & 40.0 & 36 & 40.0 \\
Cereals, flour and pasta & 35 & 38.9 & 45 & 50.0 \\
Meat and meat products & 27 & 30.0 & 18 & 20.0 \\
Other & 9 & 10.0 & 9 & 10.0 \\
\hline $\begin{array}{l}\text { Pearson Chi-Square value 5.038749 } \\
\text { df 5 }\end{array}$ & & & & \\
Asymp. Sig. (2-sided) 0.05 & & & & \\
\hline
\end{tabular}

Table 3. Percentage of organic food in total food consumption before and during the Covid-19 Pandemic

\begin{tabular}{|c|c|c|c|c|}
\hline \multirow{2}{*}{$\begin{array}{l}\text { Share in total } \\
\text { food } \\
\text { consumption }\end{array}$} & \multicolumn{2}{|c|}{ Before the Covid-19 Pandemic } & \multicolumn{2}{|c|}{ During the Covid-19 Pandemic } \\
\hline & Frequency & Percent & Frequency & Percent \\
\hline$<10 \%$ & 21 & 23.3 & 24 & 26.7 \\
\hline $11-30 \%$ & 33 & 36.7 & 27 & 30.0 \\
\hline $31-50 \%$ & 33 & 36.7 & 24 & 26.7 \\
\hline$>51 \%$ & 3 & 3.3 & 15 & 16.7 \\
\hline Total & 90 & 100.0 & 90 & 100.0 \\
\hline \multicolumn{5}{|c|}{$\begin{array}{l}\text { Pearson Chi-Square value } 10.22105 \\
\text { df } 3 \\
\text { Asymp. Sig. ( } 2 \text {-sided) } 0.05\end{array}$} \\
\hline
\end{tabular}

These results are in line with those reported in several researches conducted in previous years in Serbia (Kranjac, Vapa-Tankosić \& Knežević, 2017; Vapa-Tankosić et al., 2020). It coincides with the observations coming from a research from abroad according to which consumers consider fruits and vegetables, milk and dairy products, and cereals as the most important organic products, while the organic meat market has seen the highest trend of growth in recent years (Nguyen et al., 2019). Our results can be explained by the fact that individual farms in Serbia produce mostly vegetables, fruits, and cereals, while livestock production is much less represented (Tomaš-Simin, Glavaš-Trbić \& Petrović, 2019). Consequently, there has been greater availability of vegetables, fruits, and cereals on offer in the market that led to their 
higher consumption compared to other types of organic food from livestock production.

According to the results of the Chi-Square test, there was no statistically significant difference in the overall consumption of organic food by types before and during the Covid-19 Pandemic. However, the frequency analysis showed that there had been changes in the consumption for certain organic foods. During the Covid-19 Pandemic, fruits and vegetables were still the most dominant food in organic food consumption. However, there have been noticeable changes compared to the previous period. The most noticeable increase was in the consumption of cereals, flour, and pasta, which can be explained by the fact that due to the fear of movement bans and food shortages, consumers have increased the purchase of flour as one of the staple food. Also, there was a noticeable increase in fruit purchases, which can be explained by the increased concern of consumers for health. According to Vlahović and Šojić (2016), organic food contains higher levels of vitamin $\mathrm{C}$ and mineral elements (calcium, magnesium, iron) as well as antioxidants, which is one of the basic motives for buying organic food. A seemingly illogical figure is the decline in vegetable purchases during the Covid-19 Pandemic. However, given that the survey was conducted in early April 2020, this figure is a result of the fact that there were far fewer seasonal vegetables on offer.

According to the results of the Chi-Square test, there was a statistically significant difference in the percentage of organic food consumption in total food consumption before and during the Covid-19 Pandemic. Based on the results presented in Table 3, we can conclude that the share of organic food in total food consumption in the largest percentage of respondents before the Covid-19 Pandemic ranged between 11$30 \%$. This data coincides with research conducted in Serbia in the previous period (VapaTankosić et al., 2020). The percentage of respondents who consume organic food with a percentage above $51 \%$ of total food consumption was only $3.3 \%$. However, it is noticeable that during the Covid-19 Pandemic there were changes in the percentage share of organic food in the total consumption of respondents. Namely, the highest percentage of respondents still consumes organic food in a percentage range between $11-30 \%$, but that percentage of respondents during the Covid-19 Pandemic is lower than it was before the Covid-19 Pandemic. Also, the percentage of respondents decreased by $31-50 \%$ whereas the most significant increase was observed in the category of respondents whose share of organic food consumption exceeds $51 \%$. During the Covid19 Pandemic, the percentage of respondents consuming organic food over $51 \%$ increased by $13.4 \%$. The obtained results indicate an increase in organic food consumption during the Covid19 Pandemic. We could not find in the scientific literature how the SARS and MERS Pandemics affected the consumption of organic food so that we could compare the result. However, the result from this study harmonizes with a previous research that showed that the occurrence of crises in food production reflects an increase in the consumption of organic food (Aertsens et al., 2009; Pennings, Wansink \& Meulenberg, 2002). Moreover, it was observed that fear has an impact on the growth of organic food consumption (Vapa-Tankosić et al., 2020; Tomaš-Simin, Glavaš-Trbić \& Petrović, 2019). Numerous researches both in the world and in Serbia have shown the influence of sociodemographic characteristics of consumers on the consumption of organic food. According to Aertsens et al. (2009) several researchers have reported that a higher proportion of women hold a positive attitude and purchase organic food more often than men. Some studies found that families with children are more likely to buy organic. The findings concerning age and education seem inconsistent when considering the whole body of literature. Different surveys conducted in Serbia have given different results on the demographic profile of consumers who buy organic food in Serbia, which was explained by differences in the methodological approach in the conducted surveys (Grubor \& Djokic, 2016). Therefore, in this research, we tried to determine the demographic profile of consumers in Serbia who buy online and who consumed the most organic food during the Covid-19 Pandemic. The results are presented in Tables 4 and 5.

According to the results of the Chi-Square test, there was a statistically significant difference in the consumption of organic food depending on gender. Namely, from the results shown in Table 4, it can be concluded that men consume organic food in a relatively small amount. 
Table 4. Share of organic food in total food consumption during the Covid-19 Pandemic, depending on gender, age, and education

\begin{tabular}{|c|c|c|c|c|c|c|c|c|c|c|}
\hline \multirow{2}{*}{\multicolumn{2}{|c|}{$\begin{array}{l}\text { Share in total } \\
\text { food } \\
\text { consumption }\end{array}$}} & \multicolumn{2}{|c|}{ Gender } & \multicolumn{4}{|c|}{ Age } & \multicolumn{3}{|c|}{ Education } \\
\hline & & \multirow{2}{*}{$\frac{\text { Mail }}{12}$} & \multirow{2}{*}{$\begin{array}{c}\text { Female } \\
12\end{array}$} & \multirow{2}{*}{$\frac{<24}{9}$} & \multirow{2}{*}{$\frac{25-39}{6}$} & \multirow{2}{*}{$\frac{40-60}{9}$} & \multirow{2}{*}{$\frac{>\mathbf{6 1}}{0}$} & \multirow{2}{*}{$\begin{array}{c}\begin{array}{c}\text { High } \\
\text { school }\end{array} \\
15\end{array}$} & \multirow{2}{*}{$\frac{\mathbf{B A}}{3}$} & \multirow{2}{*}{$\begin{array}{c}\text { MA, } \\
\text { PhD } \\
6\end{array}$} \\
\hline$<10 \%$ & Count & & & & & & & & & \\
\hline$<10 \%$ & $\%$ & 57.1 & 17.4 & 42.9 & 20.0 & 25.0 & 0.0 & 38.5 & 16.7 & 18.2 \\
\hline \multirow{2}{*}{$11-30 \%$} & Count & 3 & 24 & 3 & 9 & 12 & 3 & 6 & 0 & 21 \\
\hline & $\%$ & 14.3 & 34.8 & 14.3 & 30.0 & 33.3 & 100.0 & 15.4 & 0 & 63.6 \\
\hline \multirow{2}{*}{$31-50 \%$} & Count & 3 & 21 & 6 & 12 & 6 & 0 & 12 & 6 & 6 \\
\hline & $\%$ & 14.3 & 30.4 & 28.6 & 40.0 & 16.7 & 0.0 & 30.8 & 33.3 & 18.2 \\
\hline \multirow{2}{*}{$>51 \%$} & Count & 3 & 12 & 3 & 3 & 9 & 0 & 6 & 9 & 0 \\
\hline & $\%$ & 14.3 & 17.4 & 14.3 & 10.0 & 25.0 & 0.0 & 15.4 & 50 & 0 \\
\hline \multirow{2}{*}{ Total } & Count & 21 & 69 & 21 & 30 & 36 & 3 & 39 & 18 & 33 \\
\hline & $\%$ & 100.0 & 100.0 & 100.0 & 100.0 & 100.0 & 100.0 & 100.0 & 100.0 & 100.0 \\
\hline \multicolumn{2}{|c|}{$\begin{array}{l}\text { Pearson Chi-Square } \\
\text { value }\end{array}$} & \multicolumn{2}{|c|}{13.463} & \multicolumn{4}{|c|}{17.214} & \multicolumn{3}{|c|}{43.198} \\
\hline \multicolumn{2}{|c|}{ df } & \multicolumn{2}{|c|}{3} & \multicolumn{4}{|c|}{9} & \multicolumn{3}{|c|}{6} \\
\hline \multicolumn{2}{|c|}{$\begin{array}{l}\text { Asymp. Sig. } \\
\text { (2-sided) }\end{array}$} & \multicolumn{2}{|c|}{0.004} & \multicolumn{4}{|c|}{0.045} & \multicolumn{3}{|c|}{0.000} \\
\hline
\end{tabular}

Table 5. Share of organic food in total food consumption during the Covid-19 Pandemic depending on household income and a number of household members

\begin{tabular}{|c|c|c|c|c|c|c|c|c|}
\hline \multirow{2}{*}{\multicolumn{2}{|c|}{$\begin{array}{l}\text { Share in total food } \\
\text { consumption }\end{array}$}} & \multicolumn{4}{|c|}{ Income of household } & \multicolumn{3}{|c|}{$\begin{array}{c}\text { Number of members in the } \\
\text { household }\end{array}$} \\
\hline & & \multirow{2}{*}{$\begin{array}{c}<500 \\
6\end{array}$} & \multirow{2}{*}{$\begin{array}{c}\mathbf{5 0 1 - 1 0 0 0} \\
12\end{array}$} & \multirow{2}{*}{$\begin{array}{c}\text { 1001- } \\
2000 \\
3\end{array}$} & \multirow{2}{*}{$\frac{>2001}{3}$} & \multirow{2}{*}{$\begin{array}{c}\text { 1-2 } \\
6\end{array}$} & \multirow{2}{*}{$\begin{array}{c}3-4 \\
3\end{array}$} & \multirow{2}{*}{$\begin{array}{c}\begin{array}{c}5 \text { and } \\
\text { more }\end{array} \\
15\end{array}$} \\
\hline & Count & & & & & & & \\
\hline .1070 & $\%$ & 40.0 & 40.0 & 12.5 & 14.3 & 28.6 & 10.0 & 38.5 \\
\hline \multirow{2}{*}{$11-30 \%$} & Count & 9 & 12 & 3 & 3 & 3 & 12 & 12 \\
\hline & $\%$ & 60.0 & 40.0 & 12.5 & 14.3 & 14.3 & 40.0 & 30.8 \\
\hline \multirow{2}{*}{$31-50 \%$} & Count & 0 & 3 & 9 & 12 & 9 & 6 & 9 \\
\hline & $\%$ & 0.0 & 10.0 & 37.5 & 57.1 & 42.9 & 20.0 & 23.1 \\
\hline \multirow{2}{*}{$>51 \%$} & Count & 0 & 3 & 9 & 3 & 3 & 9 & 3 \\
\hline & $\%$ & 0.0 & 10.0 & 37.5 & 14.3 & 14.3 & 30.0 & 7.7 \\
\hline \multirow{2}{*}{ Total } & Count & 15 & 30 & 24 & 21 & 21 & 30 & 39 \\
\hline & $\%$ & 100.0 & 100.0 & 100.0 & 100.0 & 100.0 & 100.0 & 100.0 \\
\hline \multicolumn{2}{|c|}{ Pearson Chi-Square value } & \multicolumn{4}{|c|}{40.809} & \multicolumn{3}{|c|}{15.833} \\
\hline \multicolumn{2}{|l|}{ df } & \multicolumn{4}{|c|}{9} & \multicolumn{3}{|c|}{6} \\
\hline \multicolumn{2}{|c|}{ Asymp. Sig. (2-sided) } & \multicolumn{4}{|c|}{0.000} & \multicolumn{3}{|c|}{0.015} \\
\hline
\end{tabular}

For $57.1 \%$ of male respondents the share of organic food in their total consumption is less than $10 \%$. Unlike men, the largest percentage of women who consume 11-30\% organic food in their total consumption is followed by an equally high percentage of women who consume organic food in the range $31-50 \%$. These figures are in line with the majority of researches conducted in Serbia that identified women as dominant consumers of higher amounts of organic food (Stojić \& Dimitrijević, 2020; Kranjac, Vapa-Tankosić \& Knežević, 2017; Grubor \& Djokic, 2016) but it is in contrast to the research of Peric, Vasic-Nikcevic \& Vujic 
(2017) which reported men as larger consumers of organic food in Serbia. Our study is in line with most research conducted around the world according to which women buy more organic food than men (Aertsens et al., 2009). Thus, the obtained results lead to the conclusion that even when it comes to the segment of consumers who buy organic food online, it is women who consume more organic food than men.

According to the results of the Chi-Square test, there was a statistically significant difference in the consumption of organic food depending on age. The results indicated that people up to the age of 24 who belong to Generation $\mathrm{Z}$ consume least organic food. As many as $42.9 \%$ of respondents under the age of 24 consume only $10 \%$ of organic food within their total food consumption. The largest consumers of organic food are people aged 25 to 39 who belong to generation Y. This group of respondents, in the largest percentage of $40 \%$, consumes organic food in the range of 31 to $50 \%$. Most members of Generation X respondents aged 40 to 60 and the Baby boomers generation over 61 (30\%) consumes $11-30 \%$ organic foods of their total consumption. These data are in line with other research conducted in Serbia, according to which the largest consumers of organic food are those aged 21 to 40, and the smallest consumers are those up to 20 years (Kranjac, Vapa-Tankosić \& Knežević, 2017). It also harmonizes with a research according to which consumers aged between 26 and 40 years are most concerned about buying organic food since more than $60 \%$ of the youngest respondents never care (Stojić \& Dimitrijević, 2020). However, some researches from Serbia report contrasting results. For example, Vlahović and Šojić (2016) found that there was no significant correlation between organic food purchases and respondents' age categories, meaning that respondents of all age categories were equally buying organic foods. Perić et al. (2017) determined that typical organic food consumption is characteristic for respondents between 41 and 50 years old. In our sample of respondents, $25 \%$ of them in the age group between 40 - 60 years have the highest share of organic product consumption (>50\%), but, the group of consumers aged 24 to 39 years who buy organic food online was identified as the largest consumer of organic food. This is in concordance with a survey conducted in Poland according to which youn- ger consumers have a greater tendency to buy organic food online (Bryła, 2018).

There is a statistically significant difference in the amount of organic food consumption depending on education. The largest percentage of respondents with high school consumes organic food at a percentage of less than $10 \%$. Respondents who have graduated from college consume the most organic food, as many as $50 \%$ of respondents consume more than $50 \%$ of organic food in total food consumption. However, the unexpected result is that the respondents who have the highest education master and doctors of science consume organic food in a percentage of 10 to $30 \%$, or less than the respondents who have a bachelor's degree. This result is in line with previous research in Serbia (Kranjac, Vapa-Tankosić \& Knežević, 2017) which showed that the largest segment of consumers of organic food is related to people with a bachelor's degree. However, it is not in line with some research in the world which indicates that education has a strong effect on the likelihood of buying organic products (Dimitri \& Dettmann, 2012; McCarthy, Liu \& Chen, 2016). Aertsens et al. (2009) state that there is no single position in the literature on how education reflects on the purchase of organic food. Therefore, the next research in Serbia should determine the reasons for the lower consumption of organic food by consumers with the highest level of education (MA and Ph.D.).

There was a statistically significant difference in the consumption of organic food between consumers depending on the level of household income (Table 5). Our data showed that consumers with the lowest income did not consume organic food at all in a percentage higher than $30 \%$. This is expected since the prices of organic food are significantly higher than those of conventional food; therefore consumers with incomes below the average in Serbia are not able to afford a higher level of consumption of organic food. Consumers with incomes between 501 and 1000 euros have a slightly higher consumption of organic food compared to consumers with incomes below 500 euros. However, the most intensive consumption of organic food is noticeable among consumers with incomes between 1001 and 2000 euros. Seventy five percent of them have a share of organic food consumption above $31 \%$ of the total diet. Also, $71.4 \%$ of respondents with incomes above 
2001 euros have a share of organic food consumption higher than $31 \%$. The obtained results indicate that consumers with higher incomes consumes more organic food within their diets which coincides with the findings of other research works conducted in Serbia. Končar et al. (2019), Vehapi and Dolićanin (2016) and Vlahović and Šojić (2016) reported similar results in line with the research of online consumers of organic food in Poland (Bryła, 2018) according to which higher-income increases the likelihood of being an organic e-consumer.

There was a statistically significant difference in the consumption of organic food depending on the number of household members. The highest percentage of respondents living in households with 3 and 4 members had the highest consumption of organic food, followed by households with 1 or 2 members, while the lowest consumption of organic food had households with 5 or more members. The obtained result can be explained by the fact that people who live in a family with one or two children, because of caring for children, buy and consume more organic food. While households with 5 or more members, due to the high price of organic food and low purchasing power in Serbia, are not able to buy larger quantities of organic food. This is in line with previous research in Serbia (Kranjac, Vapa-Tankosić \& Knežević, 2017; Vapa- Tankosić et al., 2020).

\section{CONCLUSIONS}

This research work showed that, during the Covid-19 Pandemic, the number of consumers in Serbia who buy organic food online increased by only $3.53 \%$ in the total sample. But, this increase should not be ignored. It is necessary to keep in mind that the initial percentage of consumers who buy organic food online was $5.28 \%$ and that during the Pandemic there was an increase in that percentage by $66.67 \%$. The Pandemic affected the structure of purchased organic food: consumable cereals, flour, and pasta increased the most. Also, there was a change in the share of organic food consumption in total food consumption. Changes in the percentage of online shopping as well as the type and volume of consumption of organic food can be explained by increased consumer concern for their health, as well as fear of the Covid-19.

This research pointed out the differences in the share of organic food consumption depending on the demographic characteristics of consumers who buy organic food online. During the Covid-19 Pandemic in Serbia, it was found that organic food was mostly consumed by women, members of Generation X aged 25 to 40 years, consumers living in three- and fourmember households, by those who hold $\mathrm{Ba}-$ chelor's degree and have above-average income. These indicators are useful because they represent the starting point for creation of a marketing strategy to improve the sale of organic food through online channels.

This research gave insights into just one aspect of consumers' behaviour in online shopping of organic food. The analysis of the reasons that lead consumers to use online shopping opportunities in general and in the case of organic food in particular goes beyond the scope of this research, but, it provides useful guidelines for future research.

The limitation of this research is reflected in the fact that it was limited to the territory of Serbia. It would be useful to do a similar survey in other countries so that the data obtained can be compared. Besides, it would be useful to conduct a future research on how consumers will behave after the end of the Covid-19 Pandemic and whether there will be changes in their habits when buying organic food online.

\section{REFERENCES}

Aertsens, J., Verbeke, W., Mondelaers, K., \& Van HuylenBroeck, G. (2009). Personal determinants of organic food consumption: A review. British Food Journal, 111(10), 1140-1167. https://doi.org/10.1108/00070700910992961

Aschemann-Witzel, J., \& Zielke, S. (2017). Can't buy me green? A review of consumer perceptions of and behavior toward the price of organic food. Journal of Consumer Affairs, 51(1), 211-251. https://doi.org/10.1111/joca.12092

Bryła, P. (2018). Organic food online shopping in Poland. British Food Journal, 120(5), 1015-1027. https://doi.org/10.1108/BFJ-09-2017-0517

Cane, P. (2018). Do food recalls have a greater effect on consumers' trust when they involve healthy, organic and protected designation of origin foods and, if yes, why? Journal of Agronomy Technology and Engineering Management, 1(1), 99-109.

Dašić, G., Radosavac, A., Knežević, D., \& Đervida, R. (2019). Preferences of customers and improvement of production and sales of organic products in Serbia. Ekonomika poljoprivrede, 66(1), 127-142. https://doi.org/10.5937/ekoPolj1901127D

Dimitri, C., \& Dettmann, R.L. (2012). Organic food consumers: What do we really know about them? British Food Journal, 114(8), 1157-1183. https://doi.org/10.1108/00070701211252101 
Grubor, A., \& Djokic, N. (2016). Organic food consumer profile in the Republic of Serbia. British Food Journal, 118(1), 164-182.

https://doi.org/10.1108/BFJ-06-2015-0225

Hasan, H.N., \& Suciarto, S. (2020). The influence of attitude, subjective norm and perceived behavioral control towards organic food purchase intention. $J M B E, 1(2), 132-153$.

https://doi.org/10.24167/jmbe.v1i2.2260

Hasanov, J., \& Khalid, H. (2015). The impact of website quality on online purchase intention of organic food in Malaysia: A webqual model approach. Procedia Computer Science, 72, 382-389. https://doi.org/10.1016/j.procs.2015.12.153

Končar, J., Grubor, A., Marić, R., Vukmirović, G., \& Đokić, N. (2019). Possibilities to improve the image of food and organic products on the AP Vojvodina market by introducing a regional quality label. Food \& Feed Research, 46(1), 111-123. https://doi.org/10.5937/FFR1901111K

Kranjac, M., Vapa-Tankosic, J., \& Knezevic, M. (2017). Profile of organic food consumers. Ekonomika Poljoprivrede, 64(2), 497-514. https://doi.org/10.5937/ekoPolj1702497K

McCarthy, B., Liu, H.-B., \& Chen, T. (2016). Innovations in the agro-food system: Adoption of certified organic food and green food by Chinese consumers. British Food Journal, 118(6), 1334-1349. https://doi.org/10.1108/BFJ-10-2015-0375

Mohanraj, M., Sureshkumar, J., \& Jaganathan, A.T. (2019). Customer preference towards online shopping of organic food products in Coimbatore district. IJRTE, 8(3), 6381-6384. https://doi.org/10.35940/ijrte.C5452.098319

Nguyen, H., Nguyen, N., Nguyen, B., Lobo, A., \& Vu, P. (2019). Organic food purchases in an emerging market: The influence of consumers' personal factors and green marketing practices of food stores. IJERPH, 16(6), 1037-1054. https://doi.org/10.3390/ijerph16061037

Palić, V., Cogoljević, D., Nikitović, Z., \& Vujičić, S. (2019). The consumption of organic foods by the student population in the Republic of Serbia. Ekonomika poljoprivrede, 66(3), 771-786.
https://doi.org/10.5937/ekoPolj1903771P

Pennings, J.M.E., Wansink, B., \& Meulenberg, M.T.G. (2002). A note on modeling consumer reactions to a crisis: The case of the mad cow disease. International Journal of Research in Marketing, 19(1), 91-100. https://doi.org/10.1016/S0167-8116(02)00050-2

Peric, N., Vasic-Nikcevic, A., \& Vujic, N. (2017). Consumers attitudes on organic food in Serbia and Croatia: A comparative analysis. Ekonomika Poljoprivrede, 64(3), 1049-1064. https://doi.org/10.5937/ekoPolj1703049P

Stojić, V., \& Dimitrijević, M. (2020). Consumers' intentions to use of organically produced food in the Šumadija region. Ekonomika poljoprivrede, 67(1), 253-267. https://doi.org/10.5937/ekoPolj2001253S

Tomaš-Simin, M., Glavaš-Trbić, D., \& Petrović, M. (2019). Organic production in the Republic of Serbia: Economic aspects. Ekonomija: teorija $i$ praksa, 12(3), 88-101. https://doi.org/10.5937/etp1903088T

Vapa-Tankosić, J., Ignjatijević, S., Kiurski, J., Milenković, J., \& Milojević, I. (2020). Analysis of consumers' willingness to pay for organic and local honey in Serbia. Sustainability, 12(11), 4686-4709. https://doi.org/10.3390/su12114686

Vehapi, S., \& Dolićanin, E. (2016). Consumers behavior on organic food: evidence from the republic of Serbia. Ekonomika poljoprivrede, 63(3), 871-889.

Venter, K., van der Merwe, D., de Beer, H., Kempen, E., \& Bosman, M. (2011). Consumers' perceptions of food packaging: an exploratory investigation in Potchefstroom, South Africa: Consumer perception of food packaging. International Journal of Consumer Studies, 35(3), 273-281. https://doi.org/10.1111/j.1470-6431.2010.00936.x

Vlahović, B., \& Šojić, S. (2016). Exploring consumer attitudes about organic agro-food products and their brands. Agrieconomica, 45(70), 33-46

Wanmei, C. (2018). Research on online shopping behavior of organic agricultural products based on demographic variables. $E C L, 7(3), 47-54$. https://doi.org/10.12677/ECL.2018.73007 


\title{
ПОНАШАЊЕ ПОТРОШАЧА У ОНЛАЈН КУПОВИНИ ОРГАНСКЕ ХРАНЕ ТОКОМ ПАНДЕМИЈЕ КОВИД-19 У СРБИЈИ
}

\author{
Маја Р. Ћирић*, Драган С. Илић, Светлана Д. Игњатијевић, Сандра Д. Брканлић \\ Факултет за економију и инжењерски менаџмент у Новом Саду, \\ 21000 Нови Сад, Цвећарска 2, Србија
}

Сажетак: Сврха овог рада јесте да се идентификује у којој мери је пандемија Ковид-19 утицала на промену обима онлајн куповине органске хране у Србији и да ли је довела до промена у понашању потрошача органске хране. Истраживање је спроведено на територији Србији коришћењем упитника развијеног посебно за ову намену. Укупан узорак је износио 1022 испитаника, а узорак испитаника који је онлајн куповао органску храну у току пандемије Ковид-19 износио је 90 испитаника. Дескриптивна статистика и Хи-квадрат тест коришћени су за анализу података добијених истраживањем. Добијени резултати указују да је пандемија Ковид-19 утицала на повећање процента потрошача који купују органску храну путем интернета. Такође, идентификоване су промене у врсти и обиму потрошње органске хране. Те на послетку утврђено је да је потрошња органске хране варирала у зависности од социодемографских карактеристика потрошача који су куповали путем интернета.

Кључне речи: понашање потрошача; органска храна; онлајн куповина; пандемија; Ковид-19

Received: 11 October 2020 / Received in revised form: 30 November 2020/ Accepted: 02 December 2020

Available online: December 2020

This is an open-access article under the CC BY license (http://creativecommons.org/licenses/by/3.0). 